\title{
Strategi Kreatif Iklan di Youtube
}

\author{
Niko Jorano Firdaus ${ }^{1}$, Berliana Lukitawati ${ }^{2}$, Mustopa ${ }^{3}$ \\ ${ }^{1,2,3}$ Sekolah Tinggi Ilmu Komunikasi Indonesia Maju \\ Email correspondent: nicojoranof@gmail.com
}

\begin{abstract}
Abstrak
Saat ini sudah banyak sekali konten Youtube nasional dan internasional yang dapat diakses dengan mudah oleh masyarakat. Karena lebih mudahnya proses produksi konten Youtube, mulai dari video blog aktifitas keseharian, tutorial, tips kecantikan dan lain lain. Ratusan konten kreator bersaing membuat video kreatif untuk menarik minat penonton agar memiliki viewers yang banyak. Hal ini membuat merek dagang pun ingin meramaikan sekaligus mendekatkan brand atau merek dagang terhadap audience melalui new media yang sekarang ini telah menjadi kebutuhan di digital. Tujuan dari penelitian ini yaitu untuk mengetahui bagaimana proses penerapan strategi kreatif konten terhadap audience di youtube. Penelitian ini dengan cara metode deskriptif kualitatif yang dikaitkan dengan teori advertising. Tahapan strategi kreatif ini terdiri dari tiga bagian yang disebut analisis-ideas-act karena hal ini yang menjadi acuan yang penting dalam strategi kreatif. Dari keseluruhan kesimpulan yang telah peneliti sampaikan diatas, maka saran yang dapat disampaikan adalah pentingnya tiga tahapan yaitu analytic - ideas - act dalam pembentukan ide iklan yang akan kita sampaikan kepada audience. Terlebih dari itu adapun beberapa saran dan masukan tersebut untuk Blue Bird Group harus perlu banyak lagi memberikan konten berbasis video di youtube, agar dapat memberikan pengaruh bagi generasi millenials. Semakin banyak produksi konten, semakin banyak juga animo masyarakat terutama audience digital.
\end{abstract}

Kata Kunci: strategi kreatif, penerapan, konten, youtube

\begin{abstract}
There is a lot of local and international content on Youtube that can be easily accessed by internet users. Easier process of producing Youtube content; from daily activities video blog, tutorials, beauty tips, and travel video blog, makes content creators compete to make the most creative video to attract viewers. This phenomenon also attracts brands to advertise through digital media. This research aims to find out about the creative content strategy process on Youtube could attract viewers. This study with qualitative descriptive method associated with advertising strategy. This step of creative content strategy is divided into three areas, analysis-ideas-act which is also an important reference to creative strategy. However from the overall conclusions that the researchers conveyed above, the suggestion is the importance of three stages are analytic-ideas - act to deliver a message for the audience. Moreover, the suggestions and input are that the Blue Bird Group must need a lot more to provide video-based content on YouTube to attract the millennials generation. The more you create content production, the more public interest you can get, especially the digital audience.
\end{abstract}

Keywords: creative strategy, application, content, youtube 


\section{Pendahuluan}

Transportasi merupakan bagian penting dalam hidup masyarakat.Transportasi berasal dari kata Latin yaitu transportare, di mana trans berarti seberang atau sebelah lain dan portare berarti mengangkut atau membawa. Jadi, Transportasi berarti mengangkut atau membawa (sesuatu) ke sebelah lain atau dari suatu tempat lainnya. Hal ini berarti transportasi merupakan suatu jasa yang diberikan, guna menolong orang dan barang untuk dibawa dari suatu tempat ke tempat lainnya. ${ }^{1}$

Transportasi dapat diberi definisi sebagai usaha dan kegiatan mengangkut atau membawa barang dan/atau penumpang dari suatu tempat ke tempat lainnya. Transportasi semakin berkembang mengikuti perkembangan zaman. Pada zaman dahulu transportasi dapat berupa sepeda, sepeda motor, becak, dan lain- lain. Namun di dalam perkembangannya, transportasi telah mengalami perubahan yang semakin modern, salah satunya adalah taksi.

Taksi merupakan jenis kendaraan yang disewa dengan sopir, yang digunakan oleh penumpang tunggal atau sekelompok kecil penumpang. Perkembangan Transportasi juga mencakup pada cara pemesanan dan pembayaran transaksi atas jasa transportasi.

Dahulu, pengguna jasa transportasi memesan via telpon dan kemudian membayar jasa dengan uang tunai. Pada perkembangannya saat ini, terdapat transportasi yang dapat dipesan dan dibayar secara sistem daring. Sistem daring (online). Salah satu jenis transportasi yang menggunakan sistem daring ini seperti uber, go-car, grab car, grab taxi. ${ }^{2}$

Transportasi online yang berbasis aplikasi mobile ini dapat diunduh pada smartphone pengguna jasa yang dapat digunakan dengan mudah via komputer atau smartphone yang menjadi mediasi untuk mempertemukan kebutuhan penumpang sebagai pengguna jasa dengan supir dan mobil sebagai penyedia jasa transportasi. Adapun cara pembayarannya menggunakan sistem Google Wallet, Paypal, dan kartu kredit.

Transportasi berbasis daring khususnya taksi, menawarkan kenyamanan taksi dengan harga rendah dan cukup bersaing dibandingkan dengan taksi resmi lainnya sehingga mengalami perkembangan dan pertumbuhan yang sangat cepat di tanah air maupun manca negara. ${ }^{3}$

Namun demikian, sejak peluncurannya di berbagai belahan dunia, taksi ini menuai banyak kontroversi terutama dari armada taksi resmi di Indonesia karena menggunakan mobil pribadi sebagai taksi dan tidak mempunyai status resmi yang berbadan hukum serta tidak memiliki ijin resmi beroperasi layaknya taksi resmi.

Sementara banyak perusahaan di Indonesia khususnya yang merupakan jasa transportasi darat yaitu Taksi Blue Bird merasakan ini sebagai ancaman yang mau tidak mau harus bersaing dengan sistem online yang harus ber-transformasi dari sistem lama menjadi suatu sistem yang sama sekali berbeda namun sangat cocok dengan kebutuhan masyarakat yang mempunyai mobilitas tinggi.

Namun saat ini seperti yang kita ketahui bahwa Blue Bird sebagai salah satu perusahaan transportasi terbesar di Indonesia tak hanya diam. Perusahaan transportasi yang sempat menguasi pasar taksi ini mencoba untuk ikut dalam pertandingan transportasi berbasis online, dimulai dengan produksi iklan dan kemudian pendekatan kepada audience di berbagai jejaring sosial melalui internet, salah satunya di youtube.

Media sosial kini cukup terasa dalam interaksi dan komunikasi kita, baik dalam keluarga, teman, rekan kerja dan lain-lain. Lalu bagaimana dalam hal konsumen, belanja, pasar, serta pemasaran? Jika ingin melihat hubungan antara konsumen dan merek, kita bisa mengamati grafik berikut: 


\section{JIKOM}

Jurnal Ilmiah Komunikasi

Volume 13, No.02, Juli. 2021

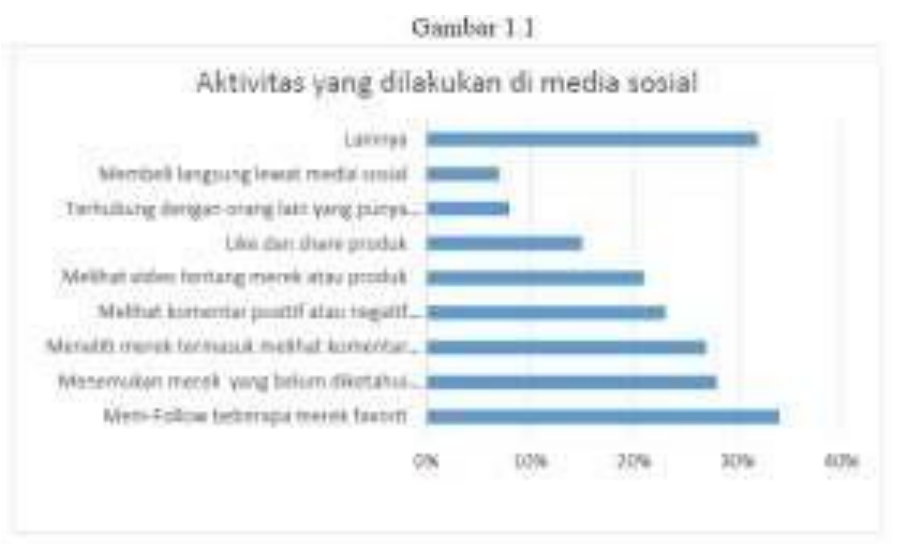

Sumber: Majalah 'Marketing’ 2017

Keterlibatan konsumen dalam media sosial telah menunjukan peningkatan. Di sisi lain, fungsi media sosial sebenarnya adalah menghubungkan orang-orang dan saling berbagi informasi. Pada grafik berikut kita bisa melihat hal-hal yang sebenernya dapat menarik para konsumen untuk berinteraksi dengan produk atau merek tertentu di media sosial. ${ }^{4}$

Dari sini para pemilik merek akan bisa mengetahui apa saja yang harus mereka lakukan atau sediakan, supaya konsumen semakin engage atau terlibat melalui media sosial.

Seperti yang sudah kita ketahui, media sosial pun hadir dalam berbagai platform. Semua platform ini idealnya ditujukan dan disesuaikan untuk mendukung pemasaran suatu produk atau merek, disertai kemampuan untuk menciptakan promosi jujur dari mulut ke mulut, pemasaran viral, dan buzz.

Selain semua bahasan tersebut, tentu muncul pertanyaan, "Platform mana yang paling digunakan untuk berbelanja iklan?" Semua media sosial seperti Facebook, Google Plus, Youtube dan Twitter intinya dapat menjangkau semua orang yang mengakses di digital hanya saja segemennya yang berebeda, kali ini penulis akan mengkaji media sosial yang berbasis video yaitu Youtube. ${ }^{5}$

Youtube telah menjadi fenomena yang mendunia, yang merupakan situs video sharing yang berfungsi sebagai sarana untuk berbagi video secara online, situs ini memfasilitasi penggunanya untuk mengupload video yang diakses oleh pengguna lain di seluruh dunia secara gratis.

Youtube merupakan database video yang paling popular di internet, dan merupakan situs video yang menyediakan berbagai informasi dan bisa diandalkan. Karena setiap orang bisa mengupload video ke akun Youtube nya sendiri, Situs ini memang disediakan bagi mereka yang ingin melakukan pencarian dan memposting kemudian menontonnya langsung. Beberapa tahun terakhir banyak bermunculan content creation yang diproduksi oleh biroiklan, mereka memanfaatkan Youtube sebagai salah satu pendekatan oleh pengiklan kepada audience yang ada di dunia digital.

Banyaknya content creation bermunculan memberikan pengaruh serta dampak banyak kepada pengiklan agar dapat memilih segment yang tepat dan tidak terkontaminasi terhadap brand lain bahkan sang kompetitor.

Tentu hal ini yang menjadi daya tarik penulis bagaimana mengemas produksi content creation membutuhkan standar kualitas dalam memberikan pesan tertentu untuk dapat menghasilkan konten audio visual yang memiliki nilai estetika dan fungsi sebagai bagian dari strategi pemasaran, tidak hanya sekedar merekam gambar dan mengedit.

Content creation harus dikemas secara menarik untuk dapat disajikan kepada audience dan segment yang tepat khususnya. ${ }^{6}$ 
Salah satu biro iklan yang membuat content creation adalah growmint digital agency, biro iklan ini sudah banyak menangani berbagai macam brand yang di dalam strateginya adalah content creation di Youtube salah satunya Blue Bird Group dalam judul bebenah.

Tujuan dari penelitian ini yaitu untuk mengetahui bagaimana proses penerapan strategi kreatif konten terhadap audience di youtube.

\section{Metode}

Penelitian ini merupakan penelitian deskriptif kualitatif yang digunakan untuk mendeskriptifkan atau memberikan gambaran dengan teknik penelitian kualitatif, yaitu mengumpulkan data berdasarkan wawancara dengan narasumber. Penelitian ini menggunakan kuesioner sebagai alat komunikasi untuk mengumpukan informasi. ${ }^{7}$ Jenis penelitian deksriptif kualitatif yang digunakan pada penelitian ini dimaksudkan untuk memperoleh informasi mengenai strategi kreatif konten yang digunakan biro iklan Growmint Digital Agency melalui media promosi Youtube dalam kampanye iklan Blue Bird Group yang berjudul Berbenah Untuk Berubah kepada masyarakat pada tanggal 25 September 2016.

Peneliti mengumpulkan data berdasarkan hasil wawancara dengan Brian Fitriyadi Jayendar selaku Creative Director, Mahar Mulyadi selaku Copy Writer, Hans Sanjayaw selaku Digital Analisis, dan Bungaran Sitohang selaku Brand Manager Blue Bird Group. Sebagai biro iklan yang memproduksi konten Berbenah Untuk Berubah tersebut dan menjadi bahan penelitian. Konten kreatif ini diupload tanggal 25 September 2016 di saluran Youtube Blue Bird Group.

Peneliti mendapatkan data sekunder dari berbagai literatur, dokumen, dan internet. Analisis data kualitatif digunakan bila data- data yang terkumpul dalam riset adalah data kualitatif. Data kualitatif dapat berupa kata- kata, kalimat-kalimat atau narasi-narasi, baik yang diperoleh dari wawancara mendalam maupun observasi. ${ }^{8}$ Selain itu Bogdan menyatakan bahwa analisis data adalah proses mencari dan menyusun secara sistematis data yang diperoleh dari hasil wawancara, catatan lapangan, dan bahan-bahan lain, sehingga dapat mudah dipahami, dan temuannya dapat diinformasikan kepada orang lain. ${ }^{9}$

Selain itu analisis data menurut Dey analisis data selalu melibatkan tiga proses yang saling terhubung satu dan lainnya yaitu: (1) Proses mendeskripsikan (Describing) menggambarkan dengan mempergunakan kata-kata, menyebutkan karakteristik- karakteristik pokok terutama dari konteks sosial, intensi aktor-aktor sosial, dan proses-proses sosial (2) Proses mengklasifikasikan (Classifying) mengelompokkan dalam kelas-kelas berupa kategori-kategori tertentu yang berguna untuk menyalurkan data dalam susunan tertentu sehingga mudah dianalisis. (3) Proses menghubungkan atau mengoneksikan (Connecting) menghubungkan kelas-kelas berupa kategori-kategori tersebut menjadi sejumlah konsep-konsep yang telah dihasilkan dalam proses mengklasifikasikan sehingga kita menemukan pola atau kerangka penalaran yang dapat menjelaskan fenomena yang diteliti. ${ }^{10}$

\section{Hasil dan Pembahasan}

Langkah awal dalam memproduksi konten kreatif Youtube Blue Bird yaitu dengan melakukan observasi. Melakukan observasi ini dimaksudkan untuk mendapatkan landasan dasar cerita yang akan dibuat. Karena dengan adanya landasan tersebut kita dapat menemukan berbagai masalah - masalah dan berbagai sentimen yang terjadi terhadap Blue Bird Group agar pesan yang ingin disampaikan tepat dan tidak menyimpang dari brief yang sudah dibuat oleh klien. ${ }^{11}$

Observasi ini dilakukan melalui beragam medianya, bisa secara interview individu, riset dengan cara online seperti menjelajah di media sosial. Pada proses ini biasanya dilakukan oleh digital analyst, digital strategic dan creative director. Seperti kutipan wawancara dengan Hans Sanjayaw selaku digital analytic dalam research untuk pembentukan ide konten kreatif Blue Bird di Youtube. ${ }^{7}$ 
Jika kita memperoleh brief dari klien biasanya kita tanya dulu ke creative director nilai apa yang mau dibentuk dan disampaikan kepada audience, kemudian mencari insight dan sentimen yang baik dan tidak baik tentang brand yang akan kita tangani, jika sudah memperoleh hasilnya, lalu di diskusikann dengan digital strategic akan dimana saja placementnya dan angle story mana yang ingin di angkat, agar tidak menjadi salah ataupun keliru dalam menyampaikan pesan.

Dari kutipan wawancara di atas penulis dapat menyimpulkan bahwa sebelum menentukan ide pesan ataupun dasar cerita ini harus didasarkan dengan problem ataupun insight yang matang agar pesan yang ingin disampaikan dalam iklan jelas dan to the point.

Insight adalah suatu wawasan orang banyak terhadap brand ataupun merek yang ingin kita cari, yang hasilnya bisa berupa sentimen negatif ataupun positif. Dalam kasus ini brand yang sedang di analisis ialah Blue Bird yang akan kita sampaikan. Selepas dari hal itu untuk menarik para penonton apa saja yang harus dilakukan dalam pengemasan konten kreatif tersebut, karena menarik perhatian dari penonton juga sangat penting dan harus dirancang dari awal. Karena keberhasilan suatu iklan dapat diukur dari seberapa besar pesan yang telah diterima oleh penonton. ${ }^{12}$

Seperti kutipan wawancara dengan Brian Fitriyadi Jayendar selaku Creative Director di Growmint agency yang memproduksi creative content di Youtube Blue Bird Group.

Kalau dari insight nya sudah benar dan tepat, kita mau membuat ide nya lebih mudah. Karena proses kreatif itu sesimple cari insight- ideas-act. Kemudian di tahap pencarian ide ini kita juga harus benar benar kerucutkan lagi, bersdasarkan insight nya, karena kalau masih terlalu luas pun juga nanti tidak akan menjadi efektif. ${ }^{13}$

Karena kita tau Blue Bird Group sebelumnya citranya dipandang sebelah mata, jadi kita harus mencari akal bagaimanapun Blue Bird harus mengklarifikasi hal itu melalui audio visual yang dikemas kedalam suatu cerita tentunya. Setelah itu kita membuat brif untuk diberikan kepada copy writer untuk mentulis cerita yang berjudul Berbenah Untuk Berubah.

Dari kutipan di atas, penulis akan menjelaskan beberapa istilah arti kata brief disini adalah suatu laporan ringkas yang menuntun. Kemudian arti insight ialah suatu wawasan yang terkait dengan brand atau merek yang akan kita teliti. Setelah dari insight kemudian ke penentuan ide cerita sudah terlalui, proses produksi konten berjalan berdasarkan timeline yang sudah ditentukan dalam project timeline. Dalam proses produksi kontennya pun sendiri ada hal hal yang harus diperhatikan agar tidak terjadi penyampaian yang diluar dari standard aturan Blue Bird. Hal ini ditegaskan oleh Mahar Mulyadi selaku Copy Writer pada iklan Blue Bird Group yang berjudul Berbenah Untuk Berubah, dalam kutipan wawancara sebagai berikut. ${ }^{14}$

Strategi dalam penulisan konten ini sendiri cukup mudah kalau kita sudah melewati tahapan research, karena dengan itu kita bisa langsung to the point menyampaikan pesan di video itu, dan tambahan berupa masukan dari creative director mengenai do and don't nya jadi tambah lebih memudahkan lagi. Ya walaupun nantinya akan ada revisi sedikit dari klien. Karena dalam hal ini pointnya cuma mau minta maaf kalau blue bird sebelumnya hanya menjadi pendengar yang baik dan sekarang izinkan kita untuk ikut pertandingan, karena kami kawan lama yang masih diandalkan. ${ }^{14}$

Dari kutipan diatas, penulis dapat menyimpulkan jika kita telah mengikuti proses tiga hal tadi insight-ideas-act, yakni dapat memudahkan berkomunikasi antar divisi agar tidak terjadi miss komunikasi. Ide-ide kreatif pun mudah diwujudkan dengan landasan tiga langkah tadi, Karena dengan langkah itu akan tersusun dengan rapih cari kita menemukan ide yang seperti kita inginkan. Karena hasil konten kreatif sebuah tim merupakan interpretasi dari kualitas biro iklan atau sering disebut agency. Seperti kutipan Brian Fitriyadi Jayendar selaku Creative Director konten kreatif Berbenah untuk berubah pada dalam kutipan wawancara sebagai berikut.

Tim strategi kreatif yang terlibat adalah karyawan Growmint, dengan tiga langkah tadi dan juga tim yang lebih minimalis sangat memudahkan komunikasi antar tim, miss komunikasi hampir tidak 
pernah terjadi. Masing masing sudah tahu perannya masing masing, sehingga akan berpengaruh pada kualitas hasil strategi konten yang akan di produksi. ${ }^{15}$

Pentingnya suatu komunikasi antar tim ataupun antar divisi dalam pembentukan strategi kreatif ini karena dapat mempengaruhi kualitas strategi yang diproduksi, karena setelah semua berjalan sesuai fungsinya masing masing, hasil strategi konten akan di kompilasi, kemudian dijadikan satu menjadi proposal yang akan di presntasikan kepdada klien.

Pemilihan judul konten kreatif Blue Bird Group Berbenah Untuk Berubah ini tercipta agar memudahkan penonton atau viewers dalam menerima pesan yang disampaikan oleh Blue Bird Group dalam konten tersebut, dan setiap strategi konten kreatif yang ada di channel Blue Bird Group diberi nama depan Blue Bird dan di tambahkan nama pesan yang ingin disampaikan melalui video dan audio. ${ }^{16}$

Seperti yang ditegaskan oleh Mahar Mulyadi selaku Copy Writer: Dalam membuat judul konten kita mau yang lebih simple dan mudah di ingat orang, tidak bertele-tele dan langsung ke intinya. Dengan judul Blue Bird Group Berebenah Untuk Berubah maka orang bisa tahu apa yang dilakukan oleh blue bird saaat ini dan kita masih kawan lama yang bisa kamu andalkan. Setiap strategi konten diharapkan membuat penonton tertarik pada video tersebut.

Alasan dalam pemilihan Youtube sebagai media beriklan dikarenakan Youtube merupakan media berbasis video yang kini telah menjadi kebutuhan para netizen, khususnya bagi mereka para konten kreator, vloger ataupun pengiklan melihat jangkauan di digital saat ini memberikan dampak lebih besar, sehingga para pengiklan berani untuk menempatkan media youtube sebagi tempat untuk beriklan.

Setelah kita memperoleh berbagai insight, hasilnya akan disajikan bisa berupa diagram ataupun persentase, dari diagaram itu kita akan tau seberapa sentimen-nya suatu brand atau merek dimata audience. Dan dengan adanya diagarm itu dapat membantu untuk mempermudah kita mencari dan membentuk ide kreatif.

Strategi kreatif konten iklan di Youtube Blue Bird Group "Berubah Untuk Berbenah" merupakan hasil dari penerapan strategi konten yang di buat oleh Growmint Digital Agency, adapun tujuan dari kreatif konten ini yaitu untuk memberi tahu kepada audience bahwa Blue Bird Group kini sudah mulai berubah dan hadir dengan jalur digital juga. ${ }^{17}$

Pendekatan iklan terhadap audience dengan cara seperti ini disebut dengan creative content yaitu sebuah cerita pendek yang berisikan pesan dari brand atau merek kepada audience melalui Youtube secara soft sell..$^{18}$

Proses konten kreatif ini terbagi menjadi tiga yaitu analisis, pencarian ide, pemilihan media, dengan adanya tahap seperti ini dapat membantu dalam proses pembentukan ide konten kreatif. Tahap analisis ini singkatnya menemukan berbagai sentimen yang terkait dengan brand atau merek di berbagai platform digital ataupun konvensional. ${ }^{19}$

Setelah menemukan beragam sentimen di berbagai platform kemudian dapat memilih salah satu sentimen tersebut sebagai dasar penentuan ide creative content, karena dengan itu kita dapat lebih to the point dalam pemilihan isi konten dalam video tersebut.

Setelah kita sudah menentukan ide Berbenah Untuk Berubah, kemudian kita menentukan platformnya apa saja yang menjadi medianya. ${ }^{20}$

Dalam konten kreatif video pemilihan judul sangat penting, Berbenah Untuk Berubah dipilih karena judul ini mudah dipahami dan mudah diingat oleh penonton atau audience, karena kemudahan mencari judul berpengaruh terhadap jumlah penonton. Proses menentukan judul juga hasil dari tiga tahapan yang penulis bahas sebelumnya. ${ }^{21}$

Ketiga tahapan proses itu sudah diterapkan, saatnya untuk meminta approval atau persetujuan dari klien, karena apapun yang terjadi didalam video tersebut menyangkut reputasi Blue Bird Group, maka itu pentingnya langkah ini agar semuanya berjalan dengan lancar sesuai yang diharapkan pihak klien maupun biro iklan. 
Setelah produksi suting berjalan sesuai plot cerita yang ditentukan dari pihak biro iklan, saatnya melihat hasil dari kualitas video konten kreatif tersebut. Hasil riset pada video Blue Bird Group yang berjudul Berbenah Untuk Berubah menghasilkan 121,624 viewers, 889 Like, 26 Dislike dan 125 komentar pada tanggal 8 July 2017.

Data tersebut membuktikan bahwa masyarakat dapat menerima video tersebut yang dikemas dengan cara menarik dengan konten yang berupa softsell dibandingkan dengan hardsell, fenomena ini membuat para Agency iklan harus melakukan hal yang tidak lagi secara hardsell dalam melakukan pendekatan terhadap konsumen atau audience, karena semakin banyak video konten kreatif yang bermunculan, semakin banyak juga pilihan penonton khususnya di youtube, tinggal bagaimana kita dapat tepat sasaran yang kita inginkan. ${ }^{3}$

\section{Kesimpulan}

Dari seluruh hasil penelitian dan pembahasan dalam skripsi ini yang telah peneliti uraikan diatas, maka dapat peneliti simpulkan sebagai berikut:

Analytic, tahap ini merupakan tahapan pencarian ataupun menemukan berbagai macam sentimen yang bisa berupa positif ataupun negatif, kemudian ketika kita sudah memperoleh hal tersebut dengan secara tidak langsung kita dapat mengidentifikasinya yang menjadi pondasi untuk membentuk ide awal dari suatu strategi pesan iklan. ${ }^{21}$

Ideas, tahapan ini kita mengindentifikasi sentimen mana yang kemudian di transformasi menjadi sebuah ide untuk menjadi key message strategi iklan yang ingin disampaikan dari Blue Bird Group kepada audience, agar permasalahan yang ada bisa terjawab melalui konten iklan yang akan kita buat.

Publish, tahapan tersebut belum lengkap apabila kita tidak merencanakan media apasaja yang ingin kita gunakan untuk mempublikasi konten iklan yang akan kita sampaikan ke audience, beragamnya sosial media menjadi salah satu tantangan kita agar dapat selektif target segmen mana yang akan menjadi utama Kali ini konten kreatif Blue Bird Group yang berjudul 'Berbenah Untuk Berubah' telah di publikasikan melalui Youtube. ${ }^{22}$

Setelah penulis amati strategi kreatif biro iklan Growmint sesuai dengan strategi kreatif yang berdasarkan teori kasali, dimana biro iklan melakukan hal berikut:

Menyiapkan informasi yang tepat sebagai strategi kreatif mereka. Dalam hal ini setelah memperoleh brief dari klien, mereka segera melakukan analisa, yaitu dengan riset untuk mengetahui insight sentimen positif atau negatif di pasar. Dengan demikian dpt diperoleh data. Selanjutnya data tsb akan digunakan untuk menentukan placement dan angle story yang akan digunakan dalam konten iklannya. Biro iklan Growmint menyebutnya sebagai langkah analitik. ${ }^{23}$

Setelah memperoleh informasi tersebut, biro iklan menetapkan posisi dalam platform serta menentukan tujuan iklan yang akan digunakan. Dalam hal ini Growmint menetapkan key message atas konten iklan bluebird versi 'berbenah untuk berubah' dengan mengatakan bahwa "kami masih kawan lama yang dapat diandalkan." Adapun penetapan key message tersebut dalam konten iklannya adalah dengan tujuan membentuk corpote image di pasar agar mereka tetap menjadikan blue bird sebagai transportasinya melalui perubahan manajemen mereka. Dalam biro iklan Growmint. Mereka menyebutnya sebagai ideas.

Langkah selanjutnya, biro iklan Growmint menyebutnya sebagai langkah act, dimana biro iklan menetapkan media yang akan digunakan untuk publikasi setelah sebelumnya melakukan presentasi pada klien untuk persetujuan rancangan iklannya. ${ }^{24}$

\section{References}




\section{JIKOM \\ Jurnal Ilmiah Komunikasi}

Volume 13, No.02, Juli. 2021

1. Rustian Kamaluddin. ekonomi transportasi karakteristik, teori dan kebijakan. Jakarta: ghalia indonesia; 2003. 13 p.

2. Yin. No Title. 2002. p. 1-4.

3. $\quad$ Lynch L. Smart Networking. Mc Graw Hill., editor. New York;

4. Marketing. : 14 .

5. Kaplan AM\& MH. Users of the world, unite! The Challenges and opportunities of social media. Business Horizons; 2010. 52 p.

6. Holt R and WI. The Holt Art Dictionary of American English. New York.; 1996. Hal.360e.

7. Sugiyono. Metode Penelitian Kuantitatif, Kualitatif dan R\&D. Bandung.: Penerbit Alfabeta,;

8. Miles dan Huberman. Analisis Data. 2010. 74 p.

9. Bodgan. No Title. 2004. 40 p.

10. Dey.I. No Title. 2003. 20 p.

11. Kim Harrison. Strategic Public Relations: A Practical Guide to Success. 2nd Edition. Australia: Vineyard Publishing;

12. Shimp TA. Advertising, Promotion, and Other Aspects of Intergrated Marketing Communications. Singapore: Cengage Learning; 2008 p.

13. Keller Larry D. \& Jugenheimer DW. Advertising Media Planning: A Brand Management Approach. New York: M.E Sharpe;

14. Kelley, Larry D. \& Jugenheimer DW. Advertising Media Planning: A Brand Management Approach. New York: M.E. Sharpe.;

15. Lin AC. Bridging Positivist and Interpretivist Approach to Qualitative Approach. 1998;(26)1: 162-80.

16. Widyatama Rendra. Pengantar Periklanan. Jakarta: Buana Pustaka Indonesia.; 2007.

17. Philip Henslowe. The Art and Science of Public Relations Vol. 3. New Delhi.: Crest Publishing House.; 2000.

18. Moriarty S. Creative Advertising Theory and practice. Engelwood; 1991.

19. Kotler P. Marketing Management 11th edition. New Jersey: Prentice Hall; 2003.

20. Kotler P. Manajemen Pemasaran. Jakarta: Erlangga; 1997.

21. Ruslan R. Metode Penelitian Public Relation dan Komunikasi. Jakarta: PT. Raja Grafindo Persada; 2003.

22. Michael BGE\& B, A. Advertising and Promotion: an Intergrated Marketing Communications Perspective. McGraw-Hill, editor. New York; 2004.

23. Puntoadi D. Menciptakan Penjualan melalui Social Media. Jakarta: PT. Elex Media Komputindo.;

24. Keller KL. Strategic brand management: building, measuring and managing brand equity. New Jersey: Prentice Hall; 2003. 